Vol 14, Issue 4, 2021

\title{
ANTIOXIDANT ACTIVITY OF METHANOL EXTRACT NATUNA MARINE SPONGE (PORIFERA) WITH DPPH METHODE
}

\author{
DELLADARI MAYEFIS*, SISKA WIDIASTUTI
}

Mitra Bunda Health Institute, Batam, Indonesia. Email: dellamayefis@gmail.com

Received: 23 October 2020, Revised and Accepted: 02 March 2021

\begin{abstract}
Objective: Natuna sponge is a marine animal that contains a wide range of secondary metabolites that can be utilized in the field of pharmacy. The research aims to test the phytochemical content and antioxidant activity of the Natuna methanol marine sponge extract. Sample extraction is done by
\end{abstract} the maceration method with methanol solvent.

Methods: Phytochemical tests include alkaloid testing, flavonoids, steroids, saponins, and tannins. Test antioxidant activity using the immersion DPPH method (1.1-diphenyl-2-picryl hydroxyl) measured absorption at a wavelength of $517 \mathrm{~nm}$.

Results: The phytochemical test results showing the sponge of Natuna contain secondary metabolites including alkaloids, flavonoids, steroids, saponins, and tannins.

Conclusion: This Natuna sponge methanol extract has an antioxidant activity that is very strong with an $\mathrm{IC}_{50}$ value of 52.91 ppm, and the comparator used is Vitamin C with an $\mathrm{IC}_{50}$ value of $43,51 \mathrm{ppm}$.

Keywords: Antioxidants, DPPH, Marine sponge, Phytochemical tests.

(C) 2021 The Authors. Published by Innovare Academic Sciences Pvt Ltd. This is an open access article under the CC BY license (http://creativecommons.org/ licenses/by/4.0/) DOI: http://dx.doi.org/10.22159/ajpcr.2021v14i4.40091. Journal homepage: https://innovareacademics.in/journals/index.php/ajpcr

\section{INTRODUCTION}

Indonesian waters, especially the Riau Islands, have abundant marine biota wealth, their use has so far been focused on fish as a food product. One type of marine biota that can be used as medicine is a sponge. Not many studies about the benefits of marine life typical of the Riau Islands are used as medicinal ingredients, especially to ward off free radicals, namely antioxidants.

Free radicals contained in the human body have the potential to inactivate various enzymes, oxidize fats, and disrupt the body's DNA so that cell mutations occur which is the beginning of cancer [1]. Free radicals can be resisted by giving antioxidants [2].

So far, people only know the source of antioxidants from plants, such as the fruits, ginger, and others [3]. Meanwhile, the source of antioxidants from marine animals is not widely known [4]. However, along with the development of technology and science, the use of antioxidants derived from marine biota is also growing, one of them by utilizing sea sponges.

Sponges from tropical Indonesian waters have very significant potential as bioactive compounds to be further developed into commodities of high economic value [5]. Sponges contain the most extensive bioactive compounds such as antibacterial activity which were isolated from Agelas clathrodes [6], antioxidant activity of Callyspongia sp. [7], and Lamellodysidea sp. [8] (Fig. 1).

Although there have been studies of antioxidant activity in sponges with maceration extraction methods and it is proven that sponges have high antioxidant activity with IC $_{50} 41.21$ ppm $[7,9,10]$, this test was carried out on sea sponges originating from the Thousand Islands with a different species from the sea sponge in Natuna. Giving rise to the thought that it is necessary to test the antioxidant activity of the Natuna marine sponge which is rich in marine biota as well as to find new medicinal ingredients.
This study aims to determine the $\mathrm{IC}_{50}$ value of the methanol extract of the Natuna sea sponge and test the activity of secondary metabolites contained therein.

\section{METHODS}

Tools and materials

The tools used include glass tools for extraction, UV-visible Spectrophotometer (Shimadzu 265). Materials used include sponges obtained from Natuna waters, Riau Islands, DPPH, Vitamin C, methanol, Liebermann-Burchard reagents, Dragendorff, Mayer, and Bouchard at.

\section{The way of research} Extraction

Fresh samples of $4 \mathrm{~kg}$ sponges that have been washed, drained, chopped, and then macerated with methanol until completely submerged in brown glass bottles and stored in a light-protected place for $3 \times 5$ days while occasionally stirring and filtered with filter paper. The methanol macerate is combined and concentrated with a rotary evaporator until a thick extract is formed then weighed to obtain $99.74 \mathrm{~g}[11,12]$.

\section{Phytochemical test extract [13]}

Alkaloid test

As much as, $4 \mathrm{ml}$ of sponge extract was put into a test tube then added $2 \mathrm{ml}$ of chloroform and $5 \mathrm{ml}$ of $10 \%$ ammonia and then added 10 drops of $2 \mathrm{M}$ sulfuric acid to clarify the separation of the formation of 2 different phases. The upper part of the formed phase is taken, and then, a Mayer reagent is added. The presence of alkaloids is characterized by the formation of red deposits.

\section{Flavonoid test}

Sponge extract is taken as much as $1 \mathrm{ml}$ added with enough magnesium powder and 10 drops of concentrated hydrochloric acid. The presence of flavonoids is characterized by the formation of reddish-black, yellow, or orange. 
Steroid test

As much as, $1 \mathrm{ml}$ of sponge extract added $2 \mathrm{ml}$ of chloroform and then shake it. Then, the filtrate was added with anhydrous acetic acid and 2 drops of concentrated sulfuric acid. A positive reaction is shown in the red color change in the first solution which turns blue and green.

Antioxidant activity test with DPPH method [14,15]

Preparation of DPPH solutions

A 50 ppm DPPH solution was prepared by weighing $5 \mathrm{mg}$ of DPPH dissolved with $100 \mathrm{ml}$ of absolute methanol in a volumetric flask [14].

\section{Preparation of sample solutions}

A 500 ppm stock solution is made by weighing $5 \mathrm{mg}$ of sponge methanol extract and dissolving it with absolute methanol while stirring and homogeneous, and then, the volume is sufficient to $10 \mathrm{ml}$ and subsequently made variations of the concentration of $10 \mathrm{ppm}, 50 \mathrm{ppm}$, 100 ppm, 150 ppm, and 200 ppm [14].

\section{Making comparative solutions}

$100 \mathrm{ppm}$ stock solution is made by weighing as much as $1 \mathrm{mg}$ of Vitamin $\mathrm{C}$ and then dissolved with absolute methanol while stirring and homogenized, and then, the volume is sufficient to $10 \mathrm{ml}$. Furthermore, variations in the concentration of $2 \mathrm{ppm}, 4 \mathrm{ppm}, 6 \mathrm{ppm}$, and $8 \mathrm{ppm}$ were made [14].

Measurement of sponge antioxidant power

The test was carried out by piping $0.5 \mathrm{ml}$ of sample solution from various concentrations ( $10 \mathrm{ppm}, 50 \mathrm{ppm}, 100 \mathrm{ppm}, 150 \mathrm{ppm}$, and $200 \mathrm{ppm}$ ), then each added $3.5 \mathrm{ml}$ of DPPH, and then Divortex and incubated at $37^{\circ} \mathrm{C}$ in a dark room. Its absorbance was measured at a wavelength of $517 \mathrm{~nm}$ [14].

Measurement of the antioxidant power of Vitamin C comparison samples

Tests carried out by pipette $0.5 \mathrm{ml}$ of Vitamin $\mathrm{C}$ solution of various concentrations ( $2 \mathrm{ppm}, 4 \mathrm{ppm}, 6 \mathrm{ppm}$, and $8 \mathrm{ppm}$ ), then each added $3.5 \mathrm{ml}$ of DPPH, and then Divortex and incubated at $37^{\circ} \mathrm{C}$ in a dark room. Its absorbance was measured at a wavelength of $517 \mathrm{~nm}$ [14].

\section{Data analysis}

The antioxidant activity of each sample and the comparative antioxidant Vitamin $\mathrm{C}$ are expressed by percent inhibition, which is calculated by the formula, and then, the data are analyzed using a linear regression equation using the Microsoft Excel program.

$$
\% \text { inhibition }=\frac{(\text { A blanko }- \text { A sample })}{\text { Ablanko }} \times 100 \%
$$

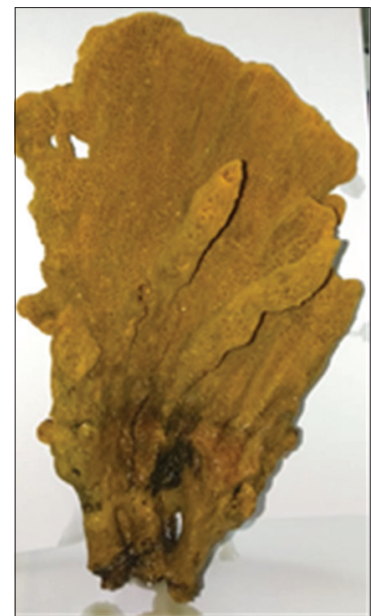

Fig. 1: Natuna sea sponge

\section{RESULTS AND DISCUSSION}

\section{Results of making sponge extracts}

Sea sponge samples were taken from the Natuna Waters of the Riau Islands precisely Kelarik Village, Bunguran Utara District, Natuna Island, Riau Islands, at a depth of $\pm 15 \mathrm{~m}$ below sea level. Then, the sponge is cleaned using seawater and running water. Samples were immediately put into bottles and soaked with methanol.

The weight of the wet sponge is $4050 \mathrm{~g}$ and then extracted with methanol solvent and obtained as much as $99.74 \mathrm{~g}$ of thick extract. Hence, we get a yield of sponge extract of $2.46 \%$.

Methanol solvents are used because methanol solvents are solvents that successfully bind the highest bioactive compounds [16]. Based on Harborne (1984) states that methanol can bind all compounds, both polar to non-polar. Widyawati [17] confirms that methanol can extract phytochemical compounds in greater amounts.

\section{Phytochemical test results of sponge extracts}

The obtained sponge extract then tested the phytochemical content to determine the class of secondary metabolite compounds contained in it. The complete results are shown in Table 1. Phytochemical testing was carried out to determine the content of compounds contained in the extract. The compounds identified include alkaloids, flavonoids, steroids, saponins, and tannins.

The results of phytochemical testing are by previous studies where sea sponges contain secondary metabolites such as alkaloids, flavonoids, and steroids $[7,8]$.

\section{Antioxidant activity test results with DPPH method}

Antioxidant activity testing is carried out by the DPPH method because this method is simple, easy, fast, and sensitive and only requires a small sample [15]. Antioxidant compounds will react with DPPH radicals through a hydrogen atom donation mechanism and cause color decay from purple to yellow [18].

In this study, the process refers to the procedure of Brand-Wiliams et al., 1995 and Handayani, 2014 with some modifications. Where the measurement of absorbance of the sample on a UV-visible spectrophotometer with a wavelength of $517 \mathrm{~nm}$ with a sample volume used of $0.5 \mathrm{~mL}$ and a DPPH of $3.5 \mathrm{~mL}$. Where the concentration of samples used was $50,100,150$, and $200 \mathrm{ppm}$, while the comparative concentrations were $2,4,6$, and $8 \mathrm{ppm}$. Where the comparison used, as positive control is Vitamin C.

Measurement of DPPH test results using a UV-visible spectrophotometer and the value of $\%$ inhibition of each concentration ( $\mathrm{IC}_{50}$ ). The $\mathrm{IC}_{50}$ value of the sponge methanol extract was $52.91 \mathrm{ppm}$. While the $\mathrm{IC}_{50}$ value of the Vitamin C comparison is $43.51 \mathrm{ppm}$, this means that the antioxidant power of sea sponge extract and Vitamin $C$ is almost the same based on the $\mathrm{IC}_{50}$ value. These results are shown in Table 2.

Based on Table 2, we can get a graph that can be seen in Fig. 2 .

Based on Table 3, we can get a graph that can be seen in Fig. 3 .

Based on the $\mathrm{IC}_{50}$ calculation results show that the Natuna sea sponge methanol extract has an $\mathrm{IC}_{50}$ value of $52.91 \mathrm{ppm}$, the smaller the

Table 1: Phytochemical test of Natuna sea sponge extract

\begin{tabular}{lll}
\hline Compound & Sponges extract & Indicator \\
\hline Alkaloid & + & Red sediment \\
Flavonoid & + & The color turns reddish-black \\
Steroid & + & The color turns green \\
Saponin & + & Formed stable foam \\
Tannin & + & Greenish black/yellow color change \\
\hline +: Contains detected compounds
\end{tabular}


Table 2: $\mathrm{IC}_{50}$ values of the Natuna sea sponge extract

\begin{tabular}{lll}
\hline Concentration (ppm) & \% Inhibition & IC $_{\mathbf{5 0}}$ (ppm) \\
\hline 50 & 42 & 52.91 \\
100 & 75 & \\
150 & 87,8 & \\
200 & 96 & \\
\hline
\end{tabular}

Table 3: $\mathrm{IC}_{50}$ values of Vitamin C

\begin{tabular}{lll}
\hline Concentration (ppm) & \% Inhibition & IC $_{\mathbf{5 0}}$ (ppm) \\
\hline 2 & 9.6 & 43.51 \\
4 & 9.9 & \\
6 & 12.5 & \\
8 & 15.34 & \\
\hline
\end{tabular}

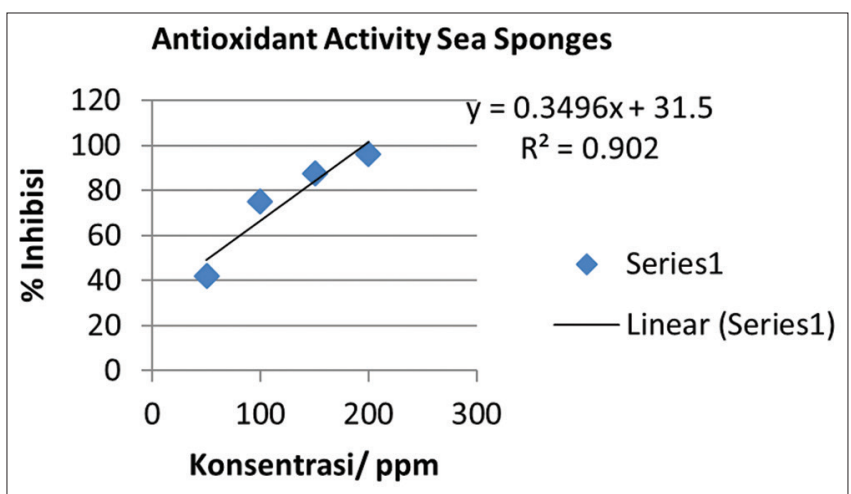

Fig. 2: Percentage curve of inhibition of sea sponge

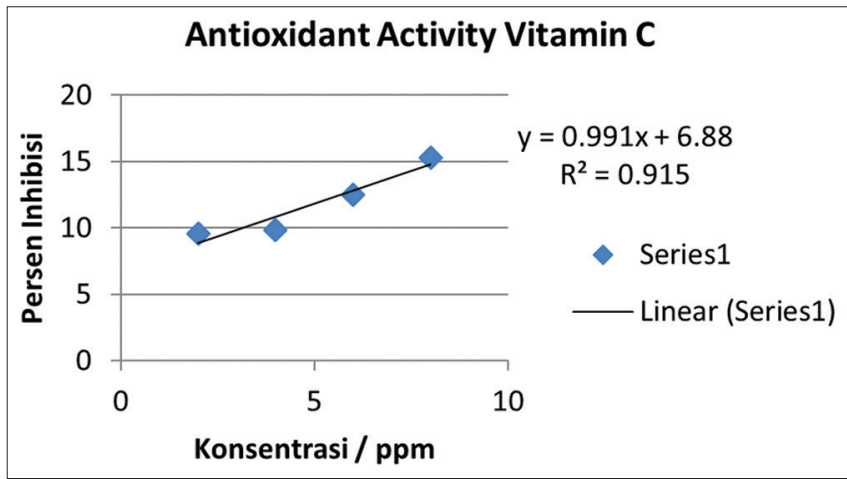

Fig. 3: Curve percentage curve of Vitamin C

$\mathrm{IC}_{50}$ value and the higher its antioxidant activity [18]. Specifically, a compound is said to be a very strong antioxidant when $\mathrm{IC}_{50}<50 \mathrm{ppm}$, strong if the $\mathrm{IC}_{50}$ value is $50-100 \mathrm{ppm}$, while if $\mathrm{IC}_{50}$ is $100-150 \mathrm{ppm}$ and is said to be weak when the $\mathrm{IC}_{50}$ value is above $150 \mathrm{ppm}[8,19]$.

According to the above classification, the Natuna sea sponge methanol extract is classified as a powerful antioxidant, because the $\mathrm{IC}_{50}$ value $<50 \mathrm{ppm}$ is equal to $52.91 \mathrm{ppm}$.

Based on the research results of compounds that have potential as antioxidants in sea sponge methanol extracts are alkaloids, flavonoids, and saponins. Where alkaloids, especially indole, can stop the reaction of free radical chain compounds efficiently. Other alkaloid compounds which are antioxidants are quinolone which can act as a radical, hydroxy, and silencer melatonin which play an important role in protecting cells from the effects of radiation and drug toxicity.
The next compound that has the potential as an antioxidant is a flavonoid which is a polyphenol compound can donate hydrogen atoms to free radical compounds, and then, the antioxidant activity of polyphenol compounds can be produced in free radical neutralization reactions or at the cessation of chain reactions that occur [20].

\section{CONCLUSION}

The secondary metabolite compounds found in the Natuna sea sponge extract based on phytochemical tests are alkaloids, flavonoids, steroids, saponins, and tannins.

Natuna sea sponge extract has a very strong antioxidant activity, with an $\mathrm{IC}_{50}$ value of $52.91 \mathrm{ppm}$.

\section{ACKNOWLEDGMENT}

The author would like to thank all those who helped to complete the research. Thank you very much to the Directorate General for Strengthening Research and Development of the Ministry of Research, Technology and Higher Education of the Republic of Indonesia, for funding this research through the Beginner Lecturer Research Grant for the 2020 Budget Year.

\section{AUTHOR'S CONTRIBUTIONS}

All the authors have contributed equally to this research work

\section{CONFLICTS OF INTEREST}

There were no conflicts of interest or financial support among the authors.

\section{AUTHOR'S FUNDING}

The experiment was funded by the Department of Pharmacy, Mitra Bunda Health Institute.

\section{REFERENCES}

1. Astuti NY. Test of DPPH Radical Capture Activity by Monoceton Curcumin and n-Heteroaliphatic Monotone Analogs (Doctoral Dissertation). Surakarta, Indonesia: Surakarta Muhammadiyah University; 2009.

2. Halliwell B. Dietary polyphenols: Good, bad, or indifferent for your health? Cardiovasc Res 2007;73:341-7.

3. Winarsi H. Natural Antioxidants and Free Radicals. Yogyakarta: Penerbit Kanisius; 2007.

4. Rahmayani U, Pringgenies D, Djunaedi A. Antioxidant activity test of mangrove snail extract (Telescopium telescopium) with different solvents to DPPH (diphenyl picric hydrazine) method. J Mar Res 2013;2:36-45.

5. Widjhati RA, Supriyono A, Subiantoro D. Development of bioactive compounds from marine biota. In: Makalah dalam Forum Bioteknologi Kelautan dan Perikanan Indonesia. Jakarta: Pusat Riset PengolahanProduk dan Sosial Ekonomi Kelautan dan Perikanan; 2004. p. 89-95.

6. Setyowati EP, Jenie UA, Kardono B, Rahmat R, Meiyanto E. Isolation of cytotoxic substance from Kaliapsis sponge. Indones $\mathrm{J}$ Pharm 2007;18:183-9.

7. Hanani E, Munim A, Sekarini R. Identification of antioxidant compounds in the Callyspongia sponges of the thousand islands. Pharm Sci Mag 2005;2

8. Rumagit HM. Phytochemical test and antioxidant activity test of ethanol extract of Lamellodysidea herbacea sponge. Pharmacon 2015;4:183-92

9. Handayani D, Handayani C, Krisyanella K. Isolation of major chemical compounds from the cytotoxic active fraction of the Petrosia sp. (MN05) sea sponge. J Farm Higea 2016;4:24-30

10. Hanani E, Munim A, Sekarini R. Identification of antioxidant compounds in sponge Callyspongia sp from the thousand islands. Pharm Sci Res 2012;2:127-33.

11. Handayani V, Ahmad AR, Sudir M. The antioxidant activity test of methanol extract of flowers and leaves of patikala (Etlingera elatior (Jack) RM Sm) using the DPPH method. Pharm Sci Res 2016;1:86-93.

12. Krisyanella HD, Yunance L. Test the cytotoxic activity of extracts and 
fractions of the Petrosia sp sea sponge by the brine shrimp lethality test method. J Sains Teknol Farm 2011;16:156-66.

13. Harborne AJ. Phytochemical Methods a Guide to Modern Techniques of Plant Analysis. Berlin: Springer Science and Business Media; 1998.

14. Mayer AM, Kossuga MH, Veloso K, Ferreira AG, Hajdu E, Berlinck RG. Antineuroinflammatory polyketide plakortide N from the Brazilian marine sponge Plakortis angulospiculatus. FASEB J 2008;22:1139.

15. Yalçın FN. Biological activities of the marine sponge Axinella. Hacettepe Üniv Ecz Fak Derg 2007;1:47-60.

16. Rachmat R, Kobayashi M, Rasyid A. Anticancer substance from sp. sp. Origin Barang Lompo, Spermonde Islands, Indonesia. In: Prosiding Seminar Laut Nasional III. 001
17. Widyawati PS, Budianta TD, Kusuma FA, Wijaya EL. Difference of solvent polarity to phytochemical content and antioxidant activity of Pluchea indicia less leaves extracts. Int J Pharmacogn Phytochem Res 2014;6:850-5

18. Molyneux P. The use of the stable free radical diphenylpicrylhydrazyl (DPPH) for estimating antioxidant activity. Songklanakarin J Sci Technol 2004;26:211-9.

19. Blois MS. Antioxidant determination by the use of stable free radical. Nature 1958;181:1199-200

20. Juniarti Departemen Biokimia FK. Analysis of secondary metabolite compounds from saurian leaf methanol extract which has potential as an antioxidant. Makara J Sci 2011; 